\title{
Analisis Masalah Heteroskedastisitas Menggunakan Generalized Least Square dalam Analisis Regresi
}

\author{
Aditya Setyawan $R^{a, *}$, Mustika Hadijatib ${ }^{b}$, Wayan Switraynic \\ a,* Program Studi Matematika,FMIPA, Universitas Mataram, Jl. Majapahit No. 62, Mataram, 83125, Indonesia. \\ Email: adityasetyawan713@gmail.com \\ b Program Studi Matematika,FMIPA, Universitas Mataram, Jl. Majapahit No. 62, Mataram, 83125, Indonesia. \\ Email: mustika.hadijati@unram.ac.id \\ c Program Studi Matematika,FMIPA, Universitas Mataram, Jl. Majapahit No. 62, Mataram, 83125, Indonesia. \\ Email: niwayan.switrayni@unram.ac.id
}

\begin{abstract}
A B S T R A C T
Regression analysis is one statistical method that allows users to analyze the influence of one or more independent variables $(X)$ on a dependent variable $(Y)$. The most commonly used method for estimating linear regression parameters is Ordinary Least Square (OLS). But in reality, there is often a problem with heteroscedasticity, namely the variance of the error is not constant or variable for all values of the independent variable $X$. This results in the OLS method being less effective. To overcome this, a parameter estimation method can be used by adding weight to each parameter, namely the Generalized Least Square (GLS) method. This study aims to examine the use of the GLS method in overcoming heteroscedasticity in regression analysis and examine the comparison of estimation results using the OLS method with the GLS method in the case of heteroscedasticity. The results show that the GLS method was able to maintain the nature of the estimator that is not biased and consistent and able to overcome the problem of heteroscedasticity, so that the GLS method is more effective than the OLS method.
\end{abstract}

Keywords: Classical Assumption Violation, Estimator Effectiveness, Generalized Least Square, Ordinary Least Square, Regression Analysis

\section{A B S T R A K}

Analisis regresi adalah salah satu metode statistik yang memungkinkan penggunanya untuk menganalisis pengaruh satu atau lebih variabel independent $(X)$ terhadap suatu varibel dependent $(Y)$. Metode yang paling umum digunakan untuk mengestimasi parameter regresi linier adalah Ordinary Least Square (OLS). Namun pada kenyataannya, sering ditemukan adanya masalah heteroskedastisitas yaitu varians dari error bersifat tidak konstan atau berubah-ubah untuk semua nilai dari variabel independent $X$. Hal ini mengakibatkan metode OLS menjadi

* Corresponding author.

Alamat e-mail: adityasetyawan713@gmail.com 
kurang efektif. Untuk mengtasi hal tersebut, dapat digunakan suatu metode estimasi parameter dengan menambahkan pembobot pada masing-masing parameter yaitu metode Generalized Least Square (GLS). Penelitian ini bertujuan untuk mengkaji penggunaan metode GLS dalam mengatasi heteroskedastisitas dalam analisis regresi dan mengkaji perbandingan hasil estimasi menggunakan metode OLS dengan metode GLS pada kasus heteroskedastisitas. Hasil penelitian menunjukkan bahwa metode GLS mampu mempertahankan sifat estimator yaitu tak bias dan konsisten serta mampu mengatasi masalah heteroskedastisitas sehingga metode GLS lebih efektif dibandingkan metode OLS.

Keywords: Efektivitas Estimator, Generalized Least Square, Ordinary Least Square, Penyimpangan Asumsi Klasik, Regresi Linier.

Diserahkan: 17-12-2019; Diterima: 31-12-2019; Doi: https://doi.org/10.29303/emj.v1i2.43

\section{Pendahuluan}

Istilah regresi pertama kali diperkenalkan oleh Sir Francis Galton pada tahun 1886. Analisis regresi pada dasarnya adalah studi mengenai ketergantungan variabel dependent (terikat) dengan satu atau lebih variabel independent (bebas), dengan tujuan untuk mengestimasi atau memprediksi rata-rata populasi atau nilai rata-rata variabel dependent berdasarkan nilai variabel independent yang diketahui (Gujarati, 2004). Dalam analisis regresi harus memperhatikan beberapa asumsi, yaitu multikolinearitas, heteroskedastisitas, autokorelasi, normalitas dan linearitas. Namun dalam penelitian ini akan difokuskan pada uji asumsi heteroskedastisitas karena di dalam beberapa kasus terlihat adanya perbedaan variansi dari error suatu pengamatan kepengamatan lain (Quadratullah, 2012). yang paling berpengaruh terhadap klasifikasi hotel di Pulau Lombok dan menentukan ketepatan klasifikasinya.

Terjadinya heteroskedastisitas dapat dilihat dari hasil estimasi Ordinary Least Square (OLS) yang diperoleh tetap bersifat linier dan tak bias, tetapi variansi yang diperoleh menjadi tidak efisien, artinya variansi cenderung membesar atau tidak lagi merupakan variansi yang minimum sehingga estimasi yang diperoleh tidak lagi BLUE (Best Linear Unbiased Estimator). Akibat dari variansi yang tidak lagi minimum yaitu perhitungan standard error metode Ordinary Least Square (OLS) menjadi tidak bisa dipercaya kebenarannya. Standard error ini memiliki peran dalam pembentukan $t$ hitung maupun $F$ hitung.

Dengan demikian masalah heteroskedastisitas harus diatasi terlebih dahulu untuk memenuhi asumsi-asumsi yang ditentukan. Ada beberapa cara untuk mengatasi heteroskedastisitas. Uthami, dkk.
(2013) mencoba mengatasi heteroskedastisitas dengan metode Regresi Kuantil Median. Selain itu heteroskedastisitas dapat pula diatasi dengan metode Generalized Least Square (GLS) yang merupakan pengembangan dari Ordinary Least Square (OLS).

Metode GLS (Generalized Least Square) dipilih dalam penelitian ini karena adanya nilai lebih yang dimiliki oleh GLS dibandingkan OLS dalam mengestimasi parameter regresi dan menurut Iswati, dkk. (2014) bahwa parameter GLS lebih efisien dan stabil dibandingkan parameter OLS. Metode OLS yang umum tidak mengasumsikan bahwa variansi variabel adalah heterogen. Metode GLS sudah memperhitungkan heterogenitas yang terdapat pada variabel independent secara eksplisit, sehingga metode ini mampu menghasilkan estimator yang memenuhi kriteria BLUE (Best Linear Unbiased Estimator) (Gujarati, 2004). Selain itu metode ini adalah untuk mencegah heteroskedastisitas agar tetap mendapatkan estimasi yang tidak bias, konsisten, dan efisien.

\section{Landasan Teori}

\subsection{Analisis Regresi}

Analisis Regresi (regression analysis) merupakan suatu teknik untuk membangun persamaan garis lurus yang selanjutnya digunakan untuk membuat suatu perkiraan. Prinsip dasar yang harus dipenuhi dalam membangun suatu persamaan regresi adalah bahwa antara variabel dependent dengan variabel independent mempunyai sifat hubungan sebab akibat (hubungan kausalitasi), baik yang didasarkan pada teori, hasil penelitian sebelumnya, ataupun yang didasarkan pada penjelasan logis tertentu (Algifari, 2000).

Bentuk umum analisis regresi adalah

$$
\begin{gathered}
Y_{i}=\beta_{0}+\beta_{1} X_{1 i}+\beta_{2} X_{2 i}+\cdots+\beta_{k} X_{k i}+\varepsilon_{i}, \\
i=1,2, \ldots, n
\end{gathered}
$$

Keterangan:

$Y_{i}$ : variabel dependent ke-i

$X_{k i} \quad$ : variabel independent dengan $k=1,2, \ldots, j$ 
$\beta_{0}, \beta_{1}, \ldots, \beta_{k}:$ parameter yang tidak diketahui nilainya dan akan diestimasi

$\varepsilon_{i}:$ variabel galat/kesalahan regresi

n : banyaknya data observasi

Untuk melakukan analisis regresi yang benar berdasarkan metode kuadrat terkecil maka harus memenuhi asumsi-asumsi yang telah ditentukan. Asumsi yang diperlukan dalam metode kuadrat terkecil, yaitu:

1. Normalitas

Asumsi kenormalan harus terpenuhi untuk mengetahui apakah error dari data berdistribusi normal atau tidak atau untuk mengetahui apakah data sampel berasal dari populasi yang berdistribusi normal.

\section{Homoskedastisitas}

Homoskedastisitas yaitu varians dari error bersifat konstan untuk semua nilai dari variabel independen $\mathrm{X}$. Uji homoskedastisitas digunakan untuk menguji apakah dalam model regresi linear error mempunyai varians yang sama atau tidak dari satu pengamatan ke pengamatan lain.

\section{Non-Autokorelasi}

Nilai error setiap pengamatan pada setiap variabel independent bersifat bebas. Uji autokorelasi digunakan untk menguji apakah dalam sebuah model regresi linear terdapat korelasi antara error pada periode $t$ dengan error pada periode $t-n$ (sebelumnya).

4. Non-Multikoliniearitas

Multikolinearitas adalah suatu kondisi dimana terjadi korelasi yang kuat diantara variabel independent yang diikutsertakan dalam pembentukan model regresi linear berganda. Jadi, Nonmultikolinearitas artinya tidak terjadi korelasi yang kuat di antara variabel independent $\mathrm{X}$.

\subsection{Heteroskedastisitas}

Menurut Nachrowi (2006) salah satu asumsi penting dalam membuat model Regresi adalah $\operatorname{var}\left(\varepsilon_{i}\right)$ harus sama dengan $\sigma^{2}$ (konstan) atau semua residual atau error mempunyai variansi yang sama. Kondisi seperti ini disebut dengan Homoskedastisitas. Sedangkan apabila variansi tidak konstan atau berubah-ubah disebut Heteroskedastisitas.

Konsekuensi dari pelanggaran asumsi homoskedastisitas adalah sebagai berikut :
1. Penduga (estimator) yang diperoleh tetap memenuhi persyaratan tidak bias. Sifat ketidak biasan tidak tergantung pada variansi galat. Jika dalam model regresi ada heteroskedastisitas, maka tetap diperoleh nilai parameter yang tidak bias karena sebagai penduga tidak bias tidak memerlukan asumsi bahwa variansi galat harus konstan.

2. Variansi penduga yang diperoleh akan menjadi tidak efisien, artinya penduga tersebut tidak memiliki variansi terkecil di antara pendugapenduga tidak bias lainnya.

Beberapa metode yang dapat digunakan untuk mendeteksi heteroskedastisitas, diantaranya adalah metode grafik dan metode Glejser.

1. Metode Grafik

Cara yang dapat digunakan untuk mendeteksi adanya heteroskdastisitas adalah dengan melihat ada tidaknya pola tertentu pada grafik, dimana sumbu $X$ adalah Y yang telah diprediksi $\hat{Y}$, dan sumbu Y adalah error. Dasar-dasar pengambilan keputusan dalam metode ini adalah:

a. Ada pola tertentu, seperti titik-titik yang membentuk suatu pola tertentu yang teratur (bergelombang melebar, kemudian menyempit) maka terjadi heteroskedastisitas.

b. Jika tidak ada pola yang jelas, serta titik-titik menyebar di atas dan di bawah angka 0 pada sumbu Y, maka tidak terjadi heteroskedastisistas.

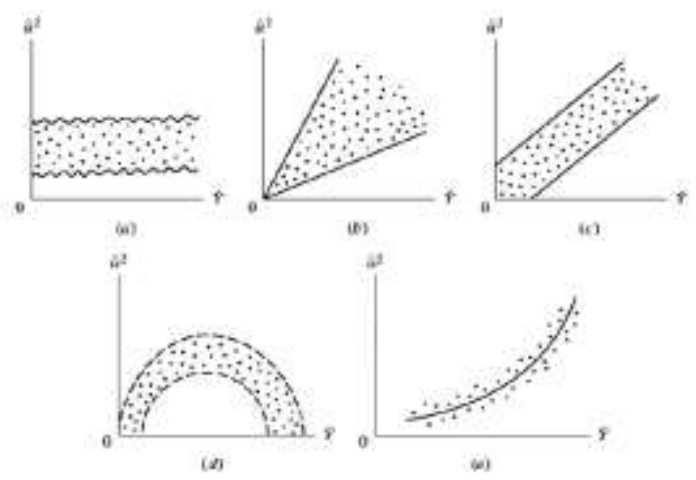

Gambar 2. 1 Pola Hipotesis Kuadrat Error yang Ditaksir

Gambar 2.1 (a) dapat dilihat bahwa tidak ada pola yang sistematis antara dua variabel yang menyatakan bahwa tidak ada heteroskedatistisitas pada data, namun gambar (b) sampai (e) menunjukkan pola tertentu yang menyatakan bahwa terdapat heteroskedastisitas pada data (Suliyanto, 2011). 
2. Metode Glejser

Uji hetroskedastisitas dengan metode Glejser dilakukan dengan meregresikan semua variabel independen terhadap nilai mutlak errornya. Jika terdapat pengaruh variabel independen yang signifikan terhadap nilai mutlak errornya maka dalam model terdapat masalah heteroskedastisitas (Suliyanto, 2011).

\subsection{Ordinary Least Square (OLS)}

Metode kuadrat terkecil adalah estimasi parameter yang sering digunakan dalam analisis regresi dengan tujuan meminimumkan jumlah kuadrat error (sum square error) (Andani dan Widodo, 2016).

Menurut Gujarati (2004), estimasi $\hat{\beta}_{0}, \hat{\beta}_{1}$, $\hat{\beta}_{2}, \ldots, \hat{\beta}_{k}$ dengan menggunakan kuadrat terkecil dapat diperoleh dengan meminimumkan jumlah kuadrat error

$\varepsilon_{i} \quad=Y_{i}-\hat{\beta}_{0}-\hat{\beta}_{1} X_{1 i}-\hat{\beta}_{2} X_{2 i}-\cdots-\hat{\beta}_{k} X_{k i}$

$\sum \varepsilon_{i}^{2}=\sum\left(Y_{i}-\hat{\beta}_{0}-\hat{\beta}_{1} X_{1 i}-\hat{\beta}_{2} X_{2 i}-\cdots-\hat{\beta}_{k} X_{k i}\right)^{2}$

Dalam notasi matriks, meminimumkan jumlah kuadrat error dapat dicapai dengan meminimumkan $\sum_{i=1}^{n} \varepsilon_{i}{ }^{2}$.

$\sum_{i=1}^{n} \varepsilon_{i}{ }^{2}=\varepsilon_{1}{ }^{2}+\varepsilon_{2}{ }^{2}+\cdots+\varepsilon_{n}{ }^{2}$

$$
\begin{aligned}
& =\left[\begin{array}{llll}
\varepsilon_{1} & \varepsilon_{2} & \ldots & \varepsilon_{n}
\end{array}\right]\left[\begin{array}{c}
\varepsilon_{1} \\
\varepsilon_{2} \\
\vdots \\
\varepsilon_{n}
\end{array}\right] \\
& =\boldsymbol{\varepsilon}^{\mathbf{T}} \boldsymbol{\varepsilon}
\end{aligned}
$$

$\operatorname{dimana} \boldsymbol{\varepsilon}=\mathbf{Y}-\mathbf{X} \widehat{\boldsymbol{\beta}}$.

Sehingga $\sum_{\mathrm{i}=1}^{\mathrm{n}} \varepsilon_{\mathrm{i}}{ }^{2}=\boldsymbol{\varepsilon}^{\mathbf{T}} \boldsymbol{\varepsilon}$

$$
\begin{gathered}
=(\mathbf{Y}-\mathbf{X} \widehat{\boldsymbol{\beta}})^{\mathbf{T}}(\mathbf{Y}-\mathbf{X} \widehat{\boldsymbol{\beta}}) \\
=\left(\mathbf{Y}^{\mathbf{T}}-\widehat{\boldsymbol{\beta}}^{\mathbf{T}} \mathbf{X}^{\mathbf{T}}\right)(\mathbf{Y}-\mathbf{X} \widehat{\boldsymbol{\beta}}) \\
=\mathbf{Y}^{\mathbf{T}} \mathbf{Y}-\mathbf{Y}^{\mathbf{T}} \mathbf{X} \widehat{\boldsymbol{\beta}}-\widehat{\boldsymbol{\beta}}^{\mathbf{T}} \mathbf{X}^{\mathbf{T}} \mathbf{Y}+\widehat{\boldsymbol{\beta}}^{\mathbf{T}} \mathbf{X}^{\mathbf{T}} \mathbf{X} \widehat{\boldsymbol{\beta}}
\end{gathered}
$$

Selanjutnya, untuk menentukan estimator regresi linear dapat dihitung dari turunan pertama persamaan (2.2) secara parsial terhadap $\widehat{\boldsymbol{\beta}}^{\mathbf{T}}$ dan disamakan hasilnya dengan nol.

$$
\begin{aligned}
& \frac{\partial\left(\varepsilon^{\mathrm{T}} \boldsymbol{\varepsilon}\right)}{\partial \widehat{\boldsymbol{\beta}}^{\mathrm{T}}}=\frac{\partial\left(\mathbf{Y}^{\mathrm{T}} \mathbf{Y}-\mathbf{Y}^{\mathrm{T}} \mathbf{X} \widehat{\boldsymbol{\beta}}-\widehat{\boldsymbol{\beta}}^{\mathrm{T}} \mathbf{X}^{\mathrm{T}} \mathbf{Y}+\widehat{\boldsymbol{\beta}}^{\mathrm{T}} \mathbf{X}^{\mathrm{T}} \mathbf{X} \widehat{\boldsymbol{\beta}}\right)}{\partial \widehat{\boldsymbol{\beta}}^{\mathrm{T}}} \\
& \frac{\partial\left(\boldsymbol{\varepsilon}^{\mathrm{T}} \varepsilon\right)}{\partial \widehat{\boldsymbol{\beta}}^{\mathrm{T}}}=-\mathbf{X}^{\mathrm{T}} \mathbf{Y}+\mathbf{X}^{\mathrm{T}} \mathbf{X} \widehat{\boldsymbol{\beta}} \\
& \frac{\partial\left(\boldsymbol{\varepsilon}^{\mathrm{T}} \varepsilon\right)}{\partial \widehat{\boldsymbol{\beta}}^{\mathrm{T}}}=0 \\
& -\mathbf{X}^{\mathrm{T}} \mathbf{Y}+\mathbf{X}^{\mathrm{T}} \mathbf{X} \widehat{\boldsymbol{\beta}}=0 \\
& \mathbf{X}^{\mathrm{T}} \mathbf{X} \widehat{\boldsymbol{\beta}}=\mathbf{X}^{\mathrm{T}} \mathbf{Y} \\
& \widehat{\boldsymbol{\beta}}=\left(\mathbf{X}^{\mathrm{T}} \mathbf{X}\right)^{-\mathbf{1}}\left(\mathbf{X}^{\mathrm{T}} \mathbf{Y}\right)
\end{aligned}
$$

\subsection{Generalized Least Square (GLS)}

Menurut (Gujarati, 2004) asumsi-asumsi yang harus dipenuhi dalam estimasi model regresi linear dengan Ordinary Least Square antara lain adalah tidak adanya autokorelasi yaitu $E(\varepsilon)=0$ dan homoskedastisitas yaitu $\operatorname{Var}(\varepsilon)=\sigma^{2} I$. Apabila asumsi-asumsi mengenai tidak adanya autokolerasi dan homoskedasitas tidak terpenuhi, maka metode Ordinary Least Square (OLS) tidak lagi tepat digunakan untuk mengestimasi parameter pada model regresi linear. Metode Generalized Least Square (GLS) dapat digunakan untuk mengestimasi parameter ketika model regresi linear berbentuk :

$\mathbf{Y}=\mathbf{X} \boldsymbol{\beta}+\boldsymbol{\varepsilon}$

dengan $E(\varepsilon)=0, \operatorname{Var}(\varepsilon)=\boldsymbol{\sigma}^{2} \mathbf{V}$ dan $\mathrm{V}$ merupakan matriks berukuran $n x n$.

Pelanggaran asumsi tidak adanya autokolerasi dan homoskedasitas akan diselesaikan dengan mentransformasi data pengamatan model regresi sehingga memenuhi asumsi-asumsi metode ordinary least square. Matriks kovariansi galat berbentuk $\boldsymbol{\sigma}^{2} \mathbf{V}$ dengan $\mathbf{V}$ merupakan matriks nonsingular dan definit positif sehingga terdapat matriks $\mathbf{K}$ simetrik non singular berukuran $n x n$ dengan $\mathbf{K}^{\prime} \mathbf{K}=\mathbf{K K}=\mathbf{V}$.

Didefinisikan variabel-variabel baru sebagai berikut,

$\mathbf{Y}^{*}=\mathbf{K}^{-1} \mathbf{Y}, \mathbf{X}^{*}=\mathbf{K}^{-1} \mathbf{X}, \boldsymbol{\varepsilon}^{*}=\mathbf{K}^{-1} \boldsymbol{\varepsilon}$,

Sehingga model regresi $\mathbf{Y}=\mathbf{X} \boldsymbol{\beta}+\boldsymbol{\varepsilon}$ menjadi $\mathbf{K}^{-\mathbf{1}} \mathbf{Y}$ $=\mathbf{K}^{-1} \mathbf{X} \boldsymbol{\beta}+\mathbf{K}^{-1} \boldsymbol{\varepsilon}$ atau

$\mathbf{Y}^{*}=\mathbf{X}^{*} \boldsymbol{\beta}+\boldsymbol{\varepsilon}^{*}$

Galat pada model yang ditransformasi memiliki nilai harapan nol, yaitu

$\mathbf{E}\left(\boldsymbol{\varepsilon}^{*}\right)=\mathbf{K}^{-1} \mathbf{E}(\boldsymbol{\varepsilon})=\mathbf{0}$

Dengan demikian, matriks kovariansi dari $\varepsilon^{*}$ dapat ditulis sebagai berikut 


$$
\begin{aligned}
& \operatorname{Var}\left(\boldsymbol{\varepsilon}^{*}\right)=\mathbf{E}\left\{\left[\boldsymbol{\varepsilon}^{*}-\mathbf{E}\left(\boldsymbol{\varepsilon}^{*}\right)\right]\left[\boldsymbol{\varepsilon}^{*}-\mathbf{E}\left(\boldsymbol{\varepsilon}^{*}\right)\right]^{\mathrm{T}}\right\} \\
& =\mathbf{E}\left(\boldsymbol{\varepsilon}^{*} \boldsymbol{\varepsilon}^{* \mathrm{~T}}\right) \\
& =\mathbf{E}\left(\mathbf{K}^{-\mathbf{1}} \boldsymbol{\varepsilon} \boldsymbol{\varepsilon}^{\mathrm{T}} \mathbf{K}^{-\mathbf{1}}\right) \\
& =\mathbf{K}^{-\mathbf{1}} \mathbf{E}\left(\boldsymbol{\varepsilon} \boldsymbol{\varepsilon}^{\mathrm{T}}\right) \mathbf{K}^{-\mathbf{1}} \\
& =\boldsymbol{\sigma}^{2} \mathbf{K}^{-1} \mathbf{V} \mathbf{K}^{-\mathbf{1}} \\
& =\boldsymbol{\sigma}^{\mathbf{2}} \mathbf{K}^{-\mathbf{1}} \mathbf{K} \mathbf{K} \mathbf{K}^{-\mathbf{1}} \\
& =\boldsymbol{\sigma}^{2} \mathbf{I}
\end{aligned}
$$

Setelah ditransformasi ternyata model regresi memenuhi asumsi regresi klasik tidak adanya autokorelasi yaitu $\mathrm{E}\left(\boldsymbol{\varepsilon}^{*}\right)=0$ dan homoskedasitas $\operatorname{Var}\left(\boldsymbol{\varepsilon}^{*}\right)=\sigma^{2}$ I. Dengan demikian dapat digunakan langkah-langkah pada metode OLS untuk mencari parameter model regresi metode GLS.

Akan dicari estimator dari parameter yang meminimumkan bentuk kuadrat

$$
\begin{aligned}
\mathbf{S}(\boldsymbol{\beta}) & =\boldsymbol{\varepsilon}^{* \mathrm{~T}} \boldsymbol{\varepsilon}^{*}=\left(\mathbf{Y}^{*}-\mathbf{X}^{*} \boldsymbol{\beta}\right)^{\mathrm{T}}\left(\mathbf{Y}^{*}-\mathbf{X}^{*} \boldsymbol{\beta}\right) \\
& =\left(\mathbf{Y}^{* \mathbf{T}}-\boldsymbol{\beta}^{\mathbf{T}} \mathbf{X}^{* \mathbf{T}}\right)\left(\mathbf{Y}^{*}-\mathbf{X}^{*} \boldsymbol{\beta}\right) \\
& =\mathbf{Y}^{* \mathrm{~T}} \mathbf{Y}^{*}-\mathbf{Y}^{* \mathrm{~T}} \mathbf{X}^{*} \boldsymbol{\beta}-\boldsymbol{\beta}^{\mathbf{T}} \mathbf{X}^{* \mathbf{T}} \mathbf{Y}^{*}+\boldsymbol{\beta}^{\mathbf{T}} \mathbf{X}^{* \mathrm{~T}} \mathbf{X}^{*} \boldsymbol{\beta}
\end{aligned}
$$

Analogi dengan metode OLS, diperoleh persamaan normal metode GLS dalam lambang matriks berbentuk :

$$
\begin{aligned}
& \left(\mathbf{X}^{* \mathrm{~T}} \mathbf{X}^{*}\right) \widehat{\boldsymbol{\beta}} \quad=\quad \mathbf{X}^{* \mathrm{~T}} \mathbf{Y}^{*} \\
& \left(\left(\mathbf{K}^{-1} \mathbf{X}\right)^{\mathrm{T}}\left(\mathbf{K}^{-\mathbf{1}} \mathbf{X}\right)\right) \widehat{\boldsymbol{\beta}}=\left(\mathbf{K}^{-\mathbf{1}} \mathbf{X}\right)^{\mathrm{T}} \mathbf{K}^{-\mathbf{1}} \mathbf{Y} \\
& \mathbf{X}^{\mathrm{T}}\left(\mathbf{K}^{-1}\right)^{\mathrm{T}} \mathbf{K}^{-1} \mathbf{X} \widehat{\boldsymbol{\beta}} \quad=\mathbf{X}^{\mathrm{T}}\left(\mathbf{K}^{-1}\right)^{\mathrm{T}} \mathbf{K}^{-1} \mathbf{Y} \\
& \left(\left(\mathbf{K}^{\mathrm{T}} \mathbf{K}\right)^{-\mathbf{1}} \mathbf{X}\right) \widehat{\boldsymbol{\beta}} \quad=\quad \mathbf{X}^{\mathbf{T}}\left(\mathbf{K}^{\mathrm{T}} \mathbf{K}\right)^{-\mathbf{1}} \mathbf{Y} \\
& \left(\mathbf{X}^{\mathrm{T}} \mathbf{V}^{-1} \mathbf{X}\right) \widehat{\boldsymbol{\beta}} \quad=\quad \mathbf{X}^{\mathrm{T}} \mathbf{V}^{-1} \mathbf{Y} \\
& \left(\mathbf{X}^{\mathrm{T}} \mathbf{V}^{-1} \mathbf{X}\right)^{-1}\left(\mathbf{X}^{\mathrm{T}} \mathbf{V}^{-1} \mathbf{X}\right) \widehat{\boldsymbol{\beta}} \\
& =\left(\mathbf{X}^{\mathbf{T}} \mathbf{V}^{-1} \mathbf{X}\right)^{-1} \mathbf{X}^{\mathbf{T}} \mathbf{V}^{-1} \mathbf{Y} \\
& \mathbf{I} \widehat{\boldsymbol{\beta}} \quad=\left(\mathbf{X}^{\mathrm{T}} \mathbf{V}^{-1} \mathbf{X}\right)^{-1} \mathbf{X}^{\mathrm{T}} \mathbf{V}^{-1} \mathbf{Y} \\
& \widehat{\boldsymbol{\beta}} \quad=\left(\mathbf{X}^{\mathrm{T}} \mathbf{V}^{-1} \mathbf{X}\right)^{-1} \mathbf{X}^{\mathrm{T}} \mathbf{V}^{-1} \mathbf{Y}
\end{aligned}
$$

Sehingga diperoleh estimator untuk GLS yaitu

$$
\widehat{\boldsymbol{\beta}} \mathbf{G L S}=\left(\mathbf{X}^{\mathrm{T}} \mathbf{V}^{-1} \mathbf{X}\right)^{-\mathbf{1}} \mathbf{X}^{\mathrm{T}} \mathbf{V}^{-1} \mathbf{Y}
$$

\section{Metode Penelitian}

Data yang digunakan pada penelitian ini adalah data bangkitan galat/error digunakan error yang mengikuti model autoregressive $\mathrm{AR}(1)$ dengan $\rho$ yang digunakan adalah $0,8,0,5$ dan 0,2 sehingga model regresi yang diperoleh memiliki sifat yang tidak independent dan heteroskedastisitas. Sedangkan data variabel bebas $X_{1}$ dan $X_{2}$ yang digunakan mengikuti sebaran uniform $(0,1)$. Alat yang digunakan pada penelitian ini adalah Software statistika Microsoft Excel 2010 dan R 3.0.3. Software tersebut digunakan untuk membantu proses pengolahan data didalam penelitian.

Secara singkat langkah-langkah yang dilakukan didalam penelitian ini dapat dibagi menjadi beberapa tahap antara lain sebagai berikut:

1. Persiapan.

2. Kajian Literatur.

3. Perbandingan Ekspektasi dan Varian OLS dan GLS.

4. Pengujian sifat estimator OLS dan GLS.

5. Membangkitkan data

6. Menentukan Variabel Y.

7. Membuat Model awal Regresi Linier dengan menggunakan OLS.

8. Uji Asumsi Homoskedastisitas dari hasil OLS.

9. Memperbaiki Model Regresi menggunakan Estimasi GLS.

10. Uji Asumsi Homoskedastisitas dari hasil GLS.

11. Membandingkan Model OLS dengan GLS

\section{Hasil dan Pembahasan}

\subsection{Kajian Teoritis Estimator OLS dan GLS}

Pada bagian ini diuraikan hasil estimator OLS dan GLS. Ordinary least square adalah estimasi parameter yang sering digunakan dalam analisis regresi dengan tujuan meminimumkan jumlah kuadrat error (sum square error) dengan estimator menurut persamaan (2.5) yaitu $\widehat{\boldsymbol{\beta}}=\left(\mathbf{X}^{\mathbf{T}} \mathbf{X}\right)^{-\mathbf{1}}\left(\mathbf{X}^{\mathbf{T}} \mathbf{Y}\right)$ sedangkan GLS (Generalized Least Square) adalah sebagai salah satu bentuk dari pengembangan estimasi least square, merupakan bentuk estimasi yang dibuat untuk mengatasi sifat heteroskedastisitas yang memiliki kemampuan untuk mempertahankan sifat efisiensi estimatornya tanpa harus kehilangan sifat unbiased dan konsistensinya dengan estimator menurut persamaan (2.10) $\widehat{\boldsymbol{\beta}}_{G L S}=$ $\left(X^{T} V^{-1} X\right)^{-1} X^{T} V^{-1} Y$ (Iswati, 2014).

Untuk membandingkan kedua metode dapat dilakukan dengan melihat sifat-sifat estimator yaitu 
estimator yang bersifat tak bias, variansi minimum dan konsisten. Akan dibandingkan kedua estimator tersebut untuk mengetahui estimator yang terbaik menurut sifat-sifat estimator.

\subsubsection{Perbandingan Sifat-Sifat Estimator OLS dan GLS}

Berikut adalah pembuktian sifat-sifat estimator untuk OLS dan GLS :

1. Tak Bias

$$
\begin{aligned}
E\left(\widehat{\boldsymbol{\beta}}_{\text {ols }}\right)= & E\left[\left(X^{T} X\right)^{-1} X^{T} Y\right] \\
& =E\left[\left(X^{T} X\right)^{-1} X^{T}(X \beta+\varepsilon)\right] \\
& =E\left[\left(X^{T} X\right)^{-1} X^{T} X \beta+\left(X^{T} X\right)^{-1} X^{T} \varepsilon\right] \\
& =E\left[I \beta+\left(X^{T} X\right)^{-1} X^{T} \varepsilon\right] \\
& =E(\beta)+E\left[\left(X^{T} X\right)^{-1} X^{T} \varepsilon\right] \\
& =\beta+\left(X^{T} X\right)^{-1} X^{T} E(\varepsilon) \\
& =\beta+0 \\
& =\beta \\
E\left(\widehat{\boldsymbol{\beta}}_{G L S}\right) & =E\left[\left(X^{T} V^{-1} X\right)^{-1} X^{T} V^{-1} Y\right] \\
& =E\left[\left(X^{T} V^{-1} X\right)^{-1} X^{T} V^{-1}(X \beta+\right. \\
& \varepsilon)] \\
& =E\left[\left(X^{T} V^{-1} X\right)^{-1} X^{T} V^{-1} X \beta+\right. \\
& \left.\left(X^{T} V^{-1} X\right)^{-1} X^{T} V^{-1} \varepsilon\right] \\
& =E\left[I \beta+\left(X^{T} V^{-1} X\right)^{-1} X^{T} V^{-1} \varepsilon\right] \\
& =E(\beta)+ \\
& E\left[\left(X^{T} V^{-1} X\right)^{-1} X^{T} V^{-1} \varepsilon\right] \\
& =\beta+\left(X^{T} V^{-1} X\right)^{-1} X^{T} V^{-1} E(\varepsilon) \\
& =\beta+0 \\
& =\beta
\end{aligned}
$$

Karena $\boldsymbol{E}\left(\widehat{\boldsymbol{\beta}}_{\text {OLS }}\right)=\boldsymbol{\beta}$ dan $\boldsymbol{E}\left(\widehat{\boldsymbol{\beta}}_{\text {GLS }}\right)=\boldsymbol{\beta}$ maka estimator OLS dan GLS memenuhi sifat tak bias.

2. Variansi

$$
\begin{aligned}
\widehat{\boldsymbol{\beta}}_{\text {oLS }} & =\widehat{\boldsymbol{\beta}}-\boldsymbol{\beta} \\
& =\left(X^{T} X\right)^{-1} X^{T} Y-\beta \\
& =\left(X^{T} X\right)^{-1} X^{T}(X \beta+\varepsilon)-\beta \\
& =\left(X^{T} X\right)^{-1}\left(X^{T} X\right) \beta+\left(X^{T} X\right)^{-1} X^{T} \varepsilon-\beta \\
& =I \beta+\left(X^{T} X\right)^{-1} X^{T} \varepsilon-\beta \\
& =\left(X^{T} X\right)^{-1} X^{T} \varepsilon \\
\operatorname{var}\left(\widehat{\beta}_{O L S}\right) & =E\left[(\widehat{\beta}-\beta)(\widehat{\beta}-\beta)^{T}\right] \\
& =E\left[\left(\left(X^{T} X\right)^{-1} X^{T} \varepsilon\right)\left(\left(X^{T} X\right)^{-1} X^{T} \varepsilon\right)^{T}\right] \\
& =E\left[\left(X^{T} X\right)^{-1} X^{T} \varepsilon \varepsilon^{T} X\left(X^{T} X\right)^{-1}\right]
\end{aligned}
$$

$$
\begin{aligned}
= & \left(X^{T} X\right)^{-1} X^{T} E\left(\varepsilon \varepsilon^{T}\right) X\left(X^{T} X\right)^{-1} \\
= & \left(X^{T} X\right)^{-1} X^{T} \sigma^{2} I X\left(X^{T} X\right)^{-1} \\
= & \sigma^{2}\left(X^{T} X\right)^{-1} X^{T} X\left(X^{T} X\right)^{-1} \\
= & \sigma^{2}\left(X^{T} X\right)^{-1} \\
\widehat{\beta}_{G L S}= & \widehat{\beta}-\beta \\
= & \left(X^{T} V^{-1} X\right)^{-1} X^{T} V^{-1} Y-\beta \\
= & \left(X^{T} V^{-1} X\right)^{-1} X^{T} V^{-1}(X \beta+\varepsilon)-\beta \\
= & \left(X^{T} V^{-1} X\right)^{-1}\left(X^{T} V^{-1} X\right) \beta+ \\
& \left(X^{T} V^{-1} X\right)^{-1} X^{T} V^{-1} \varepsilon-\beta \\
= & I \beta+\left(X^{T} V^{-1} X\right)^{-1} X^{T} V^{-1} \varepsilon-\beta \\
= & \left(X^{T} V^{-1} X\right)^{-1} X^{T} V^{-1} \varepsilon \\
\operatorname{var}\left(\widehat{\beta}_{G L S}\right)= & E\left[\left(\widehat{\beta}^{-\beta}\right)(\widehat{\beta}-\beta)^{T}\right] \\
= & E\left[\left(\left(X^{T} V^{-1} X\right)^{-1} X^{T} V^{-1} \varepsilon\right)\right. \\
& \left.\left(\left(X^{T} V^{-1} X\right)^{-1} X^{T} V^{-1} \varepsilon\right)^{T}\right] \\
= & E\left[\left(X^{T} V^{-1} X\right)^{-1} X^{T} \varepsilon \varepsilon^{T} V^{-1} X\left(X^{T} V^{-1} X\right)^{-1}\right] \\
= & \left(X^{T} V^{-1} X\right)^{-1} X^{T} E\left(\varepsilon \varepsilon^{T}\right) V^{-1} X\left(X^{T} V^{-1} X\right)^{-1} \\
= & \left(X^{T} V^{-1} X\right)^{-1} X^{T} \sigma^{2} I V^{-1} X\left(X^{T} V^{-1} X\right)^{-1} \\
= & \sigma^{2}\left(X^{T} V^{-1} X\right)^{-1} X^{T} V^{-1} X\left(X^{T} V^{-1} X\right)^{-1} \\
= & \sigma^{2}\left(X^{T} V^{-1} X\right)^{-1} \\
&
\end{aligned}
$$

\section{Konsisten}

Untuk menentukan estimator bersifat konsisten menggunakan ketidaksamaan Chebyshev's yaitu :

$$
P\left(\left|X-\mu_{\bar{x}}\right|<k \sigma_{\bar{x}}\right) \geq 1-\frac{1}{k^{2}}
$$

Diperoleh :

$$
\begin{aligned}
& \text { a. } \quad \mu_{\bar{x}}=E\left(\hat{\beta}_{O L S}\right)=\beta \\
& \text { b. } \quad \sigma_{\bar{x}}^{2}=\operatorname{var}\left(\hat{\beta}_{O L S}\right)=\sigma^{2}\left(X^{T} X\right)^{-1} \\
& \text { Jadi: } \quad P\left(|\hat{\beta}-\beta|<k \sigma_{\widehat{\beta}}\right) \geq 1-\frac{1}{k^{2}} \\
& \text { Misalkan : } \varepsilon=k \frac{\sigma}{\sqrt{X^{T} X}} \\
& k=\frac{\varepsilon \sqrt{X^{T} X}}{\sigma} \\
& k^{2}=\frac{\varepsilon^{2}\left(X^{T} X\right)}{\sigma^{2}}
\end{aligned}
$$

Sehingga : 


$$
\begin{aligned}
& P(|\hat{\beta}-\beta|<\varepsilon) \geq 1-\frac{1}{\frac{\varepsilon^{2}\left(X^{T} X\right)}{\sigma^{2}}} \\
& P(|\hat{\beta}-\beta|<\varepsilon) \geq 1-\frac{\sigma^{2}}{\varepsilon^{2}\left(X^{T} X\right)} \\
& \lim _{x \rightarrow \infty} P(|\hat{\beta}-\beta|<\varepsilon) \geq \lim _{x \rightarrow \infty}\left(1-\frac{\sigma^{2}}{\varepsilon^{2}\left(X^{T} X\right)}\right)=
\end{aligned}
$$

Dengan demikian $\hat{\beta}_{O L S}$ merupakan estimator konsisten bagi $\beta$,sedangkan $\hat{\beta}_{G L S}$ analogi dengan OLS didapatkan :

$$
\begin{gathered}
\lim _{x \rightarrow \infty} P(|\hat{\beta}-\beta|<\varepsilon) \geq \lim _{x \rightarrow \infty}\left(1-\frac{\sigma^{2}}{\varepsilon^{2}\left(X^{T} V^{-1} X\right)}\right) \\
=1
\end{gathered}
$$

Sehingga $\hat{\beta}_{G L S}$ juga memenuhi sifat estimator yang konsisten.

\subsubsection{Pembahasan Hasil Perbandingan Estimator OLS dan GLS}

Dari hasil perbandingan estimator OLS dan GLS berdasarkan sifat estimator, diketahui bahwa estimator OLS dan GLS memenuhi sifat estimator tak bias dan konsisten. Namun, jika dibandingkan dengan sifat variansi minimum bahwa GLS lebih efisien karena memliki variansi lebih minimum sehingga metode GLS lebih dapat digunakan untuk melakukan estimasi parameter. GLS (Generalized Least Square) sebagai salah satu bentuk dari pengembangan estimasi least square, merupakan bentuk estimasi yang dibuat untuk mengatasi sifat heteroskedastisitas yang memiliki kemampuan untuk mempertahankan sifat efisiensi estimatornya tanpa harus kehilangan sifat unbiased dan konsistensinya. Walaupun metode ini merupakan pengembangan Ordinary Least Square untuk mengatasi heteroskedastisitas, namun metode ini juga bisa digunakan pada data yang homoskedastisitas.

\subsection{Penerapan Prosedur Estimasi pada Data Bangkitan}

Pada bagian ini diuraikan hasil penerapan estimasi regresi dengan GLS pada data bangkitan yang diolah menggunakan software matematika $\mathrm{R}$ i386 3.4.1. Data yang dibangkitkan merupakan pasangan data dari model regresi linier berganda dengan dua variabel bebas dan satu variabel terikat. Pada pembangkitan galat/error digunakan error yang mengikuti model autoregressive orde $\mathrm{AR}(1)$ dengan $\rho$ yang digunakan adalah $0.8,0.5$ dan 0.2 sehingga memungkinkan model regresi yang diperoleh memiliki sifat yang tidak independent dan heteroskedastisitas. Sedangkan data variabel bebas $X_{1}$ dan $X_{2}$ yang digunakan mengikuti sebaran uniform $(0,1)$. Adapun data variabel terikat, diperoleh dengan beberapa persamaan, yaitu $Y_{i}=X_{1 i}+X_{2 i}+$ $e$

Data bangkitan yang digunakan merupakan pasangan data dengan beberapa $n$, yaitu $n=30 n=$ 60 dan $n=100$.

\subsubsection{Hasil Penerapan untuk Data Simulasi dengan $Y_{i}=X_{1 i}+X_{2 i}+e$}

Berdasarkan data bangkitan uniform berukuran $n=$ 30 dengan data minimum 0 dan data maksimum 1 dengan $Y_{i}=X_{1 i}+X_{2 i}+e$ dan error mengikuti AR(1) dengan $\rho=0,8$ dilakukan estimasi parameter regresi dengan metode OLS menggunakan persamaan normal yang disusun dalam bentuk matriks pada persamaan sebagai berikut:

$$
\begin{aligned}
{\left[\begin{array}{c}
\hat{\beta}_{0} \\
\hat{\beta}_{1} \\
\hat{\beta}_{2}
\end{array}\right] } & =\left[\begin{array}{ccc}
N & \sum x_{1} & \sum x_{2} \\
\sum x_{1} & \sum x_{1}{ }^{2} & \sum x_{1} x_{2} \\
\sum x_{2} & \sum x_{1} x_{2} & \sum x_{2}{ }^{2}
\end{array}\right]^{-1}\left[\begin{array}{c}
\sum y \\
\sum x_{1} y \\
\sum x_{2} y
\end{array}\right] \\
& =\left[\begin{array}{ccc}
30 & 15,97 & 18,13 \\
15,97 & 10,08 & 9.56 \\
18,13 & 9.56 & 13,29
\end{array}\right]^{-1}\left[\begin{array}{l}
20,14 \\
15,04 \\
17,97
\end{array}\right] \\
& =\left[\begin{array}{ccc}
0,39 & -0,35 & -0,27 \\
-0,35 & 0,64 & 0,02 \\
-0,27 & 0,02 & 0,43
\end{array}\right]\left[\begin{array}{l}
20,14 \\
15,04 \\
17,97
\end{array}\right] \\
& =\left[\begin{array}{c}
-2,43 \\
2,89 \\
2,59
\end{array}\right]
\end{aligned}
$$

Berikut ini adalah hasil estimasi OLS menggunakan software $\mathrm{R}$ dalam bentuk tabel dan diperoleh hasil berikut

Tabel 4. 1 Hasil OLS untuk bangkitan

$$
Y_{i}=X_{1 i}+X_{2 i}+e
$$

\begin{tabular}{ccc}
\hline Variabel & Estimate & Varian \\
\hline Konstanta & -2.43 & 0.39 \\
$X 1$ & 2.89 & 0.64 \\
$X 2$ & 2.59 & 0.43 \\
\hline
\end{tabular}

Berdasarkan tabel 4.1 didapatkan nilai sebesar $-2,43$ untuk parameter regresi $\beta_{0}, 2,89$ untuk parameter $\beta_{1}, 2,59$ untuk parameter $\beta_{2}$ dengan Varian masing-masing sebesar $0,39,0,64$ dan 0,43 sehingga model yang terbentuk adalah :

$$
Y=-2.43+2.89 X_{1}+2.59 X_{2}
$$


Berdasarkan model yang terbentuk dilakukan pengujian asumsi kenormalan, homoskedastisitas, dan independensi error sebagai berikut :

\section{Normalitas Error}

Untuk memeriksa asumsi kenormalan, dapat digunakan metode Kolmogorov-Smirnov yang memiliki keakuratan yang cukup baik dengan hipotesis :

$\mathrm{H}_{0}$ : error mengikuti distribusi normal

$\mathrm{H}_{1}$ : error tidak mengikuti distribusi normal

Dari hasil menggunakan software dengan persamaan $D=\sup \left|S(e)-F_{0}(e)\right|$ didapatkan $\mathrm{D}=0,12$ dan $p$ value $=0,2$ dengan $\alpha=0,05$, karena $p$-value $>\alpha$ maka $\mathrm{H}_{0}$ diterima sehingga dapat dikatakan error mengikuti distribusi Normal.

\section{Homoskedastisitas Error}

Pemeriksaan asumsi homoskedastisitas dapat dilakukan dengan metode Glejser yaitu meregresikan semua variabel independen terhadap nilai mutlak errornya. Dengan hipotesis sebagai berikut :

$\mathrm{H}_{0}$ : error mempunyai varian yang sama atau tidak terjadi heteroskedastisitas

$\mathrm{H}_{1}$ : error mempunyai varian berbeda atau terjadi heteroskedastisitas

Tabel 4. 2 Hasil Uji Glejser OLS untuk data bangkitan $|\varepsilon|=X_{1 i}+X_{2 i}+e$

\begin{tabular}{ccccc}
\hline Variabel & Estimate & $\begin{array}{c}\text { Standard } \\
\text { Eror }\end{array}$ & $\begin{array}{c}\mathrm{t}- \\
\text { hitung }\end{array}$ & $\begin{array}{c}\boldsymbol{p} \text { - } \\
\text { value }\end{array}$ \\
\hline Konstanta & 0.02 & 0.63 & 0.04 & 0.97 \\
$X 1$ & 0.89 & 0.81 & 1.09 & 0.29 \\
$X 2$ & 1.48 & 0.67 & 2.22 & 0.04 \\
\hline
\end{tabular}

Berdasarkan tabel 4.2 dapat dilihat nilai $p$-value $<$ $\alpha=0,05$ adalah parameter $\beta_{2}$ sebesar 0,04 yang artinya $\mathrm{H}_{0}$ ditolak, sehingga dapat disimpulkan bahwa error mempunyai varian berbeda atau terjadi heteroskedastisitas.

\section{Independensi Error}

Salah satu uji yang dapat dilakukan untuk menguji Independensi error adalah uji Durbin Watson. Pada uji Durbin Watson, hipotesis yang diuji adalah

$\mathrm{H}_{0}: \rho_{s}=0$

$\mathrm{H}_{1}: \rho_{s} \neq 0$

Dengan $n=30$ dan $k=2$ didapat nilai $\mathrm{dL}$ sebesar 1,18 dan dU sebesar 1,46 dari tabel Durbin
Watson, sedangkan hasil analisis Durbin-Watson dengan nilai statistik uji diperoleh berdasarkan persamaan sebagai berikut:

$$
\begin{aligned}
D W & =\frac{\sum_{i=1}^{n}\left(\varepsilon_{i}-\varepsilon_{i-1}\right)^{2}}{\sum_{i=1}^{n}\left(\varepsilon_{i}\right)^{2}} \\
& =0,65
\end{aligned}
$$

didapatkan nilai $D W=0,65$. Karna nilai $D W<d L$ maka $\mathrm{H}_{0}$ ditolak sehingga dapat disimpulkan bahwa asumsi independensi tidak terpenuhi.

Berdasarkan uji asumsi tersebut, dapat dilihat bahwa terjadi masalah heteroskedastisitas. Karena terjadi kasus heteroskedastisitas maka estimator OLS tidak menghasilkan estimator yang BLUE (Best Linear Unbiased Estimator). Sehingga dapat dilakukan uji estimasi lanjutan menggunakan metode Generalized Least Square untuk mengatasi kasus heteroskedastisitas. Estimasi menggunakan metode GLS dilakukan dengan cara menambahkan bobot pada parameter yang mengalami masalah heteroskedastisitas. Bobot yang digunakan adalah $V=\frac{1}{\left(1-\rho^{2}\right)}\left[\begin{array}{ccccc}1 & \rho & \rho^{2} & \cdots & \rho^{49} \\ \rho & 1 & \rho & \cdots & \rho^{48} \\ \rho^{2} & \rho & 1 & \cdots & \rho^{47} \\ \vdots & \vdots & \vdots & \ddots & \vdots \\ \rho^{49} & \rho^{48} & \rho^{47} & \cdots & 1\end{array}\right]$

Karena error mengikuti AR(1) dengan nilai $\rho$ adalah parameter dari $\operatorname{AR}(1)$ yaitu $\rho=0.8$ menurut Iswati, (2014). Sehingga dilakukan estimasi menggunakan GLS dan diperoleh hasil sebagai berikut :

Tabel 4. 3 Hasil GLS untuk data bangkitan

$$
Y_{i}=X_{1 i}+X_{2 i}+e
$$

\begin{tabular}{ccc}
\hline Variabel & Estimate & Varian \\
\hline Konstanta & -0.57 & 0.87 \\
$X 1$ & -0.08 & 0.57 \\
$X 2$ & 1.34 & 0.31 \\
\hline
\end{tabular}

Berdasarkan tabel 4.3 hasil estimasi dengan GLS memberikan estimasi parameter $\beta_{0}=-0.57, \beta_{1}=$ -0.08 dan $\beta_{2}=1.34$ dengan Varian masing-masing sebesar $0.87,0.57$ dan 0.31 sehingga model yang terbentuk adalah :

$$
Y=-0.57+-0.08 X_{1}+1.34 X_{2}
$$

\section{Normalitas Error}

Untuk memeriksa asumsi kenormalan, dapat digunakan metode Kolmogorov-Smirnov yang memiliki keakuratan yang cukup baik dengan hipotesis : 
$\mathrm{H}_{0}$ : error mengikuti distribusi normal

$\mathrm{H}_{1}$ : error tidak mengikuti distribusi normal

Dari hasil software dengan persamaan $D=\sup \left|S(e)-F_{0}(e)\right|$ didapatkan $\mathrm{D}=0.11$ dan $p$ -

value $=0.2$ dengan $\alpha=0,05$, karena $p-$ value $>\alpha$ maka $\mathrm{H}_{0}$ diterima sehingga dapat dikatakan error mengikuti distribusi Normal.

\section{Homoskedastisitas Error}

Pemeriksaan asumsi homoskedastisitas dapat dilakukan dengan metode Glejser yaitu meregresikan semua variabel independen terhadap nilai mutlak errornya. Dengan hipotesis sebagai berikut :

$\mathrm{H}_{0}$ : error mempunyai varian yang sama atau tidak terjadi heteroskedastisitas

$\mathrm{H}_{1}$ : error mempunyai varian berbeda atau terjadi heteroskedastisitas

Tabel 4. 4 Hasil Uji Glejser GLS untuk data bangkitan $|\varepsilon|=\boldsymbol{X}_{1 i}+\boldsymbol{X}_{\mathbf{2 i}}+\boldsymbol{e}$

\begin{tabular}{ccccc}
\hline Variabel & Estimate & $\begin{array}{c}\text { Standard } \\
\text { Eror }\end{array}$ & $\begin{array}{c}\text { t- } \\
\text { hitung }\end{array}$ & $\begin{array}{c}\boldsymbol{p} \text { - } \\
\text { value }\end{array}$ \\
\hline Konstanta & 1.08 & 0.78 & 1.39 & 0.18 \\
$X 1$ & 0.17 & 1.00 & 0.17 & 0.87 \\
$X 2$ & 0.63 & 0.82 & 0.77 & 0.45 \\
\hline
\end{tabular}

Berdasarkan tabel 4.4 dapat dilihat nilai parameter memiliki nilai $p$-value $>\alpha=0,05$ yang artinya $\mathrm{H}_{0}$ diterima, sehingga dapat disimpulkan bahwa error mempunyai varian yang sama atau tidak terjadi heteroskedastisitas.

\section{Independensi Error}

Salah satu uji yang dapat dilakukan untuk menguji Independensi error adalah uji Durbin Watson. Pada uji Durbin Watson, hipotesis yang diuji adalah

$\mathrm{H}_{0}: \rho_{s}=0$

$\mathrm{H}_{1}: \rho_{s} \neq 0$

Dengan $n=30$ dan $k=2$ didapat nilai $\mathrm{dL}$ sebesar 1,18 dan dU sebesar 1,46 dari tabel Durbin Watson, sedangkan hasil analisis Durbin-Watson dengan nilai statistik uji diperoleh berdasarkan persamaan sebagai berikut:

$$
\begin{aligned}
D W & =\frac{\sum_{i=1}^{n}\left(\varepsilon_{i}-\varepsilon_{i-1}\right)^{2}}{\sum_{i=1}^{n}\left(\varepsilon_{i}\right)^{2}} \\
& =0,27
\end{aligned}
$$

didapatkan nilai $D W=0,27$. Karna nilai $D W<d L$ maka $\mathrm{H}_{0}$ ditolak sehingga dapat disimpulkan bahwa asumsi independensi tidak terpenuhi.

Untuk $\mathrm{Y}$ yang dibagkitkan dengan $\mathrm{Y}_{\mathrm{i}}=\mathrm{X}_{1}+$ $\mathrm{X}_{2}+\mathrm{e}$, error tidak hanya dibangkitkan dengan $\rho=$ 0,8 tetapi dengan $\rho=0,5$ dan $\rho=0,2$. Ringkasan hasilnya diperoleh seperti pada tabel 4.5 berikut :

Tabel 4. 5 Ringkasan Hasil Estimasi OLS untuk

\begin{tabular}{|c|c|c|c|c|c|c|c|}
\hline $\mathbf{N}$ & $\begin{array}{c}\mathbf{A R}( \\
\phi)\end{array}$ & $\begin{array}{c}\mathbf{P a} \\
\mathbf{r}\end{array}$ & $\begin{array}{c}\text { Estim } \\
\text { asi }\end{array}$ & $\begin{array}{c}\text { Varia } \\
\mathbf{n}\end{array}$ & $\begin{array}{l}\text { Nor } \\
\text { mal }\end{array}$ & $\begin{array}{c}\text { OLS } \\
\text { Hom } \\
\text { os }\end{array}$ & $\begin{array}{c}\text { Independ } \\
\text { ensi }\end{array}$ \\
\hline \multirow[t]{9}{*}{30} & \multirow[t]{3}{*}{0,8} & $\beta_{0}$ & -2.43 & 0.39 & \multirow[t]{3}{*}{ ya } & \multirow[t]{3}{*}{ tidak } & \multirow[t]{3}{*}{ tidak } \\
\hline & & $\beta_{1}$ & 2.89 & 0.64 & & & \\
\hline & & $\beta_{2}$ & 2.59 & 0.43 & & & \\
\hline & \multirow[t]{3}{*}{0,5} & $\beta_{0}$ & -0.35 & 0.16 & \multirow[t]{3}{*}{ ya } & \multirow[t]{3}{*}{ tidak } & \multirow[t]{3}{*}{ tidak } \\
\hline & & $\beta_{1}$ & 2.32 & 0.39 & & & \\
\hline & & $\beta_{2}$ & 1.52 & 0.33 & & & \\
\hline & \multirow[t]{3}{*}{0,2} & $\beta_{0}$ & -0.12 & 0.24 & \multirow[t]{3}{*}{ ya } & \multirow[t]{3}{*}{ tidak } & \multirow[t]{3}{*}{ ya } \\
\hline & & $\beta_{1}$ & 0.99 & 0.38 & & & \\
\hline & & $\beta_{2}$ & 1.22 & 0.43 & & & \\
\hline \multirow[t]{9}{*}{60} & \multirow[t]{3}{*}{0,8} & $\beta_{0}$ & -0.40 & 0.09 & \multirow[t]{3}{*}{ ya } & \multirow[t]{3}{*}{ tidak } & \multirow[t]{3}{*}{ tidak } \\
\hline & & $\beta_{1}$ & 1.05 & 0.19 & & & \\
\hline & & $\beta_{2}$ & 1.52 & 0.18 & & & \\
\hline & \multirow[t]{3}{*}{0,5} & $\beta_{0}$ & -0.63 & 0.12 & \multirow[t]{3}{*}{ ya } & \multirow[t]{3}{*}{ tidak } & \multirow[t]{3}{*}{ tidak } \\
\hline & & $\beta_{1}$ & 1.18 & 0.22 & & & \\
\hline & & $\beta_{2}$ & 1.67 & 0.23 & & & \\
\hline & \multirow[t]{3}{*}{0,2} & $\beta_{0}$ & -0.11 & 0.09 & \multirow[t]{3}{*}{ ya } & \multirow[t]{3}{*}{ tidak } & \multirow[t]{3}{*}{ ya } \\
\hline & & $\beta_{1}$ & 1.41 & 0.20 & & & \\
\hline & & $\beta_{2}$ & 1.01 & 0.20 & & & \\
\hline 10 & \multirow[t]{3}{*}{0,8} & $\beta_{0}$ & 1.06 & 0.09 & \multirow[t]{3}{*}{ ya } & \multirow[t]{3}{*}{ tidak } & \multirow[t]{3}{*}{ tidak } \\
\hline \multirow[t]{8}{*}{0} & & $\beta_{1}$ & 1.47 & 0.12 & & & \\
\hline & & $\beta_{2}$ & -0.11 & 0.12 & & & \\
\hline & 0,5 & $\beta_{0}$ & 0.06 & 0.07 & ya & tidak & tidak \\
\hline & & $\beta_{1}$ & 0.96 & 0.14 & & & \\
\hline & & $\beta_{2}$ & 1.12 & 0.12 & & & \\
\hline & 0,2 & $\beta_{0}$ & -0.00 & 0.02 & ya & tidak & tidak \\
\hline & & $\beta_{1}$ & 0.99 & 0.00 & & & \\
\hline & & $\beta_{2}$ & 0.95 & 0.00 & & & \\
\hline
\end{tabular}
data bangkitan $\boldsymbol{Y}_{\boldsymbol{i}}=\boldsymbol{X}_{\mathbf{1 i}}+\boldsymbol{X}_{\mathbf{2 i}}+\boldsymbol{e}$

Tabel 4. 6 Ringkasan Hasil Estimasi GLS untuk

\begin{tabular}{|c|c|c|c|c|c|c|c|}
\hline \multirow[t]{2}{*}{$\mathbf{N}$} & \multirow{2}{*}{$\begin{array}{c}\mathbf{A R}( \\
\phi)\end{array}$} & \multirow{2}{*}{$\mathbf{P a}$} & \multirow[b]{2}{*}{$\begin{array}{c}\text { Estim } \\
\text { asi }\end{array}$} & \multicolumn{4}{|c|}{ OLS } \\
\hline & & & & $\begin{array}{c}\text { Varia } \\
n\end{array}$ & $\begin{array}{l}\text { Nor } \\
\text { mal }\end{array}$ & $\begin{array}{c}\text { Hom } \\
\text { os }\end{array}$ & $\begin{array}{c}\text { independ } \\
\text { ensi }\end{array}$ \\
\hline \multirow[t]{8}{*}{30} & 0,8 & $\beta_{0}$ & -0.57 & 0.87 & ya & ya & Tidak \\
\hline & & $\begin{array}{l}\beta_{1} \\
\beta_{2}\end{array}$ & $\begin{array}{c}-0.08 \\
1.34\end{array}$ & $\begin{array}{l}0.57 \\
0.31\end{array}$ & & & \\
\hline & 0,5 & $\beta_{0}$ & -0.25 & 0.25 & ya & ya & Tidak \\
\hline & & $\beta_{1}$ & 1.35 & 0.36 & & & \\
\hline & & $\beta_{2}$ & 0.98 & 0.25 & & & \\
\hline & 0,2 & $\beta_{0}$ & -0.04 & 0.23 & ya & ya & Ya \\
\hline & & $\beta_{1}$ & 0.90 & 0.36 & & & \\
\hline & & $\beta_{2}$ & 1.11 & 0.40 & & & \\
\hline \multirow[t]{4}{*}{60} & 0,8 & $\beta_{0}$ & -0.38 & 0.41 & ya & ya & Tidak \\
\hline & & $\beta_{1}$ & 1.09 & 0.11 & & & \\
\hline & & $\beta_{2}$ & 1.11 & 0.12 & & & \\
\hline & 0,5 & $\beta_{0}$ & -0.39 & 0.15 & ya & ya & Tidak \\
\hline
\end{tabular}
data bangkitan $\boldsymbol{Y}_{\boldsymbol{i}}=\boldsymbol{X}_{\mathbf{1 i}}+\boldsymbol{X}_{\mathbf{2 i}}+\boldsymbol{e}$ 


\begin{tabular}{cccccccc} 
& & $\beta_{1}$ & 0.67 & 0.19 & & & \\
& & $\beta_{2}$ & 1.69 & 0.18 & & & \\
& & & & & & \\
& 0,2 & $\beta_{0}$ & -0.02 & 0.09 & ya & ya & Ya \\
& & $\beta_{1}$ & 1.28 & 0.19 & & & \\
10 & & $\beta_{2}$ & 0.95 & 0.21 & & & \\
0 & 0,8 & $\beta_{0}$ & 0.79 & 0.27 & ya & ya & tidak \\
& & $\beta_{1}$ & 1.13 & 0.07 & & & \\
& & $\beta_{2}$ & 0.89 & 0.07 & & & \\
& 0,5 & $\beta_{0}$ & 2.34 & 0.08 & ya & ya & tidak \\
& & $\beta_{1}$ & 0.48 & 0.09 & & & \\
& & $\beta_{2}$ & -1.42 & 0.09 & & & \\
& 0,2 & $\beta_{0}$ & 0.03 & 0.02 & ya & ya & tidak \\
& $\beta_{1}$ & 0.97 & 0.00 & & & \\
& $\beta_{2}$ & 0.93 & 0.00 & & & \\
\hline
\end{tabular}

Dari hasil tabel 4.5 dan 4.6 dapat dibentuk grafik untuk varian OLS dan GLS seperti berikut :
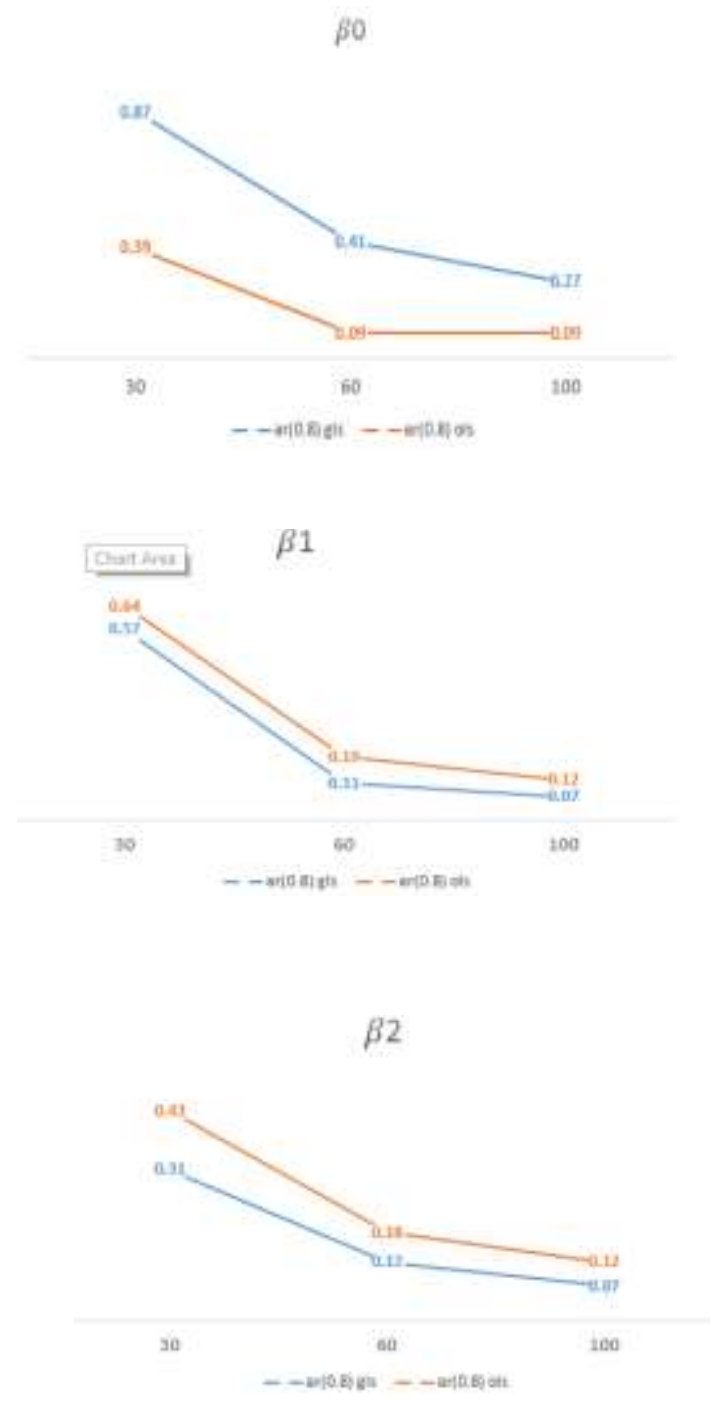

Gambar 4.1 Nilai Variansi OLS dan GLS AR $(\rho=$ 0.8)
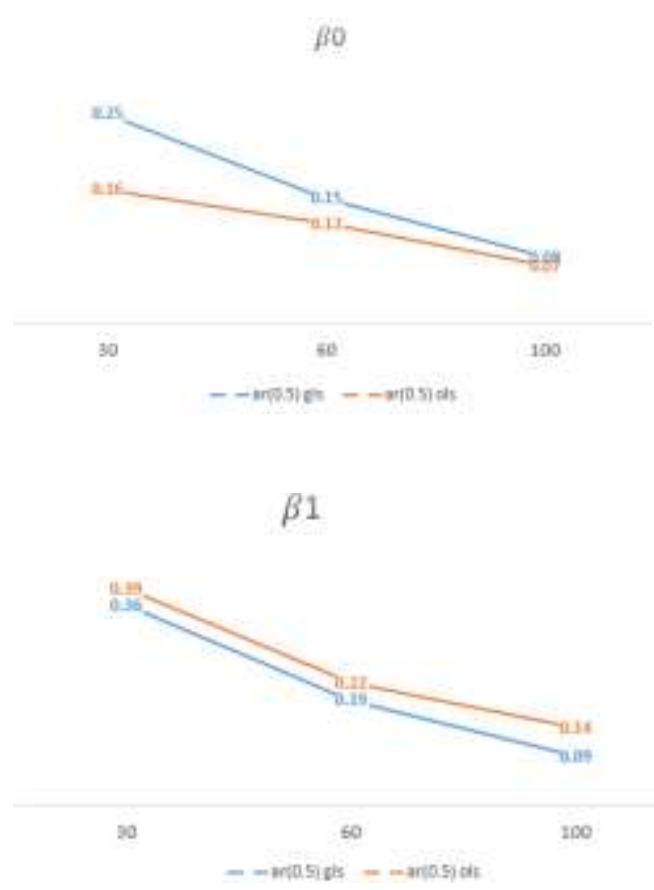

$\beta 2$
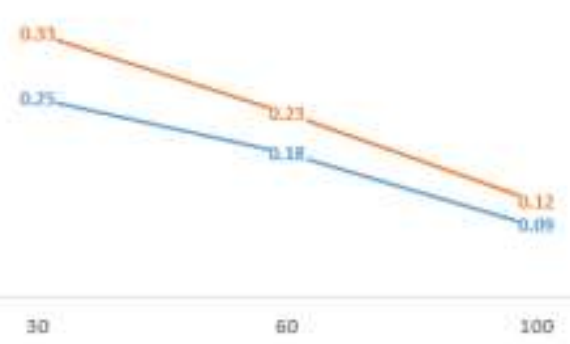

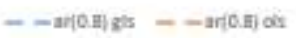

Gambar 4.2 Nilai Variansi OLS dan $\operatorname{GLS} \operatorname{AR}(\rho=$ $0.5)$

$\beta 0$

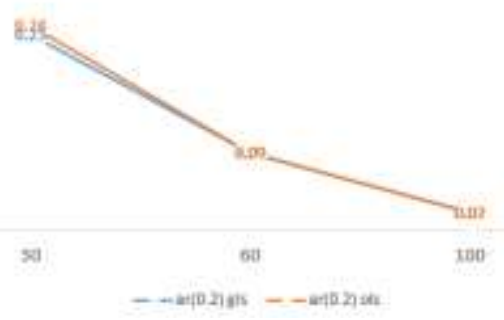




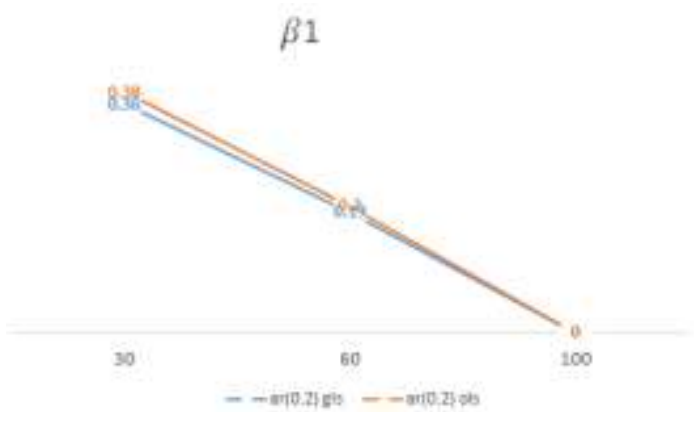

$\beta 2$

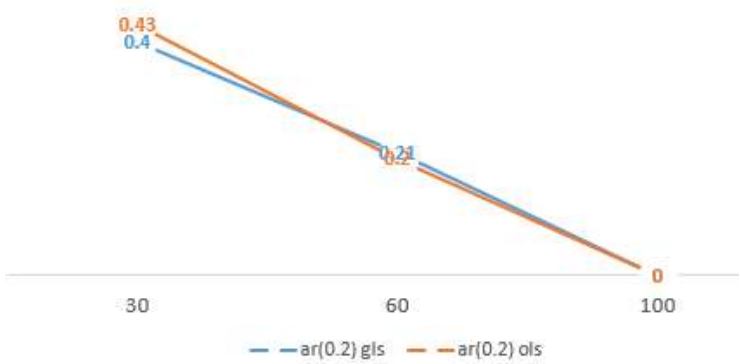

Gambar 4.3 Nilai Variansi OLS dan $\operatorname{GLS} \operatorname{AR}(\rho=$ $0.2)$

\subsubsection{Pembahasan Hasil Penerapan Prosedur Estimasi pada Data Bangkitan}

Berdasarkan ringkasan hasil estimasi dengan OLS dan GLS pada tabel 4.5 dan tabel 4.6 dapat dilihat bahwa hasil estimasi menggunakan metode GLS mampu mempertahankan asumsi kenormalan dan mampu mengatasi masalah heteroskedastisitas, tapi metode GLS tidak mampu mengatasi masalah independensi error, sehingga dapat dilakukan transformasi data untuk mengatasi masalah independensi error. Hasil estimasi menggunakan metode GLS mampu mempertahankan sifat-sifat estimator yaitu mempertahankan sifat tak bias dan konsisten, dan memiliki nilai varian yang lebih minimum dibandingkan metode OLS tergantung nilai dari bobotnya.

Pada gambar 4.1, gambar 4.2, dan gambar 4.3 dapat dilihat bahwa nilai varian GLS lebih kecil dari nilai varian OLS sehingga dapat dikatakan bahwa metode GLS lebih baik dari metode OLS. Dari gambar 4.1 sampai gambar 4.3 dapat dilihat bahwa nilai varian akan semakin kecil mendekati nilai nol apabila datanya semakin besar.

\section{Kesimpulan}

Berdasarkan hasil analisis data dan pembahasan, dapat ditarik kesimpulan sebagai berikut :

1. Estimasi menggunakan metode Generalized Least Square dilakukan dengan cara menambahkan bobot pada parameter yang mengalami masalah heteroskedastisitas. Bobot yang digunakan tergantung dari nilai error yang dibangkitkan dengan estimatornya adalah

$\widehat{\boldsymbol{\beta}}_{G L S}=\left(X^{T} V^{-1} X\right)^{-1} X^{T} V^{-1} Y$.

2. Hasil perbandingan sifat-sifat estimator OLS dan GLS adalah sama-sama memenuhi sifat estimator yang tak bias dan konsisten, tetapi jika dilihat dari variansinya maka estimator GLS memiliki variansi yang lebih minimum dari estimator OLS sehingga estimator GLS lebih efisien dari estimator OLS. Sedangkan perbandingan model OLS dan GLS adalah model GLS lebih baik karena dapat mengatasi heteroskedastisitas yang terjadi.

\section{DAFTAR PUSTAKA}

Adani dan Widodo, 2016, Perbandingan Kemampuan Regresi Kuantil Median dan Transformasi Box-Cox dalam Mengatasi Heteroskedastisitas, Konferensi Nasional Penelitian Matematika dan Pembelajarannya (KNPMP I), Universitas Muhammadiyah Surakarta, 12 Maret 2016.

Algifari, 2000, Analisis Regresi: Teori, Kasus dan Solusi, Edisi kedua, BPFE-Yogyakarta, Yogyakarta.

Gujarati, D.N., 2004, Basic Econometric, Mc Graw Hill, New York.

Iswati, Helmi, Rahmat Syahni, dan Maiyastri, 2014, Perbandingan Penduga Ordinary Least Square $(O L S)$ dan Generalized Least Square (GLS) Pada Model Regresi Linier dengan Regresor Bersifat Stokastik dan Galat Model Berautokeralas, Jurnal Matematika UNAND Vol.3 No.4 Hal.168-176.

Nachrowi, Djalal, dan Hardius Usman, 2006, Pendekatan Populer dan Praktis Ekonometrika Untuk Analisis Ekonomi dan Keuangan, FEUI.

Quadratullah, M. 2012, Analisis Regresi Terapan Teori, Contoh Kasus, dan Aplikasi dengan SPSS, ANDI, Yogyakarta.

Suliyanto, 2011, Ekonometri Terapan : Teori dan Aplikasi dengan SPSS, Andi Yogyakarta, Purwokerto. 
Uthami, dkk., 2013, Regresi Kuantil Median untuk Mengatasi Heteroskedastisitas pada Analisis Regresi, E-Jurnal Matematika Vol.2, No.1, Januari 2013, 6-13. 